\title{
Characterization of uptake and compartmentalization of 3,5,3'-tri-iodothyronine in cultured neonatal rat cardiomyocytes
}

\author{
H H A G M van der Putten, B J L J Joosten, P H M Klaren \\ and $\mathbf{M}$ E Everts
}

Department of Veterinary Anatomy and Physiology, Utrecht University, PO Box 80157, 3508 TD Utrecht, The Netherlands

(Requests for offprints should be addressed to M E Everts, Department of Veterinary Anatomy and Physiology, Faculty of Veterinary Medicine, Utrecht University, PO Box 80157, 3508 TD Utrecht, The Netherlands; Email: m.everts@vet.uu.nl)

\begin{abstract}
The uptake of tri-iodothyronine $\left(\mathrm{T}_{3}\right)$ in cultured neonatal rat cardiomyocytes was investigated and compared with the uptake of reverse $\mathrm{T}_{3}\left(\mathrm{rT}_{3}\right)$ and thyroxine $\left(\mathrm{T}_{4}\right)$. Cellular compartmentalization of $\mathrm{T}_{3}$ was studied by distinguishing $\mathrm{T}_{3}$ activity associated with the plasma membrane from that in the cytosol or incorporated in the cell nucleus. $\mathrm{T}_{3}$ and $\mathrm{T}_{4}$ uptake displayed similar temperature dependencies which, in magnitude, differed from that of $\mathrm{rT}_{3}$ uptake. $\mathrm{T}_{3}$ uptake was $\mathrm{Na}^{+}$independent, and sensitive to oligomycin and monodansylcadaverine $(42-49 \%$ and $25 \%$ inhibition of 15-min cellular uptake respectively). Furthermore, $\mathrm{T}_{3}$ uptake could be inhibited by tryptophan $(20 \%)$ and tyrosine (12\%), while 2-aminobicyclo[2,2,1]heptanecarboxylic acid had no effect. Co-incubation with tryptophan and oligomycin resulted in an additive inhibition of $\mathrm{T}_{3}$ uptake (77\%). We therefore conclude that (i) $\mathrm{T}_{3}$ uptake is energy dependent, (ii) receptor-mediated endocytosis may be involved and (iii) the aromatic amino acid
\end{abstract}

transport system $\mathrm{T}$ may play a role, while system $\mathrm{L}$ is not involved in $\mathrm{T}_{3}$ transport in cardiomyocytes. Co-incubation with unlabeled iodothyronines showed that 3,3'-di-iodothyronine and $\mathrm{T}_{3}$ itself were the most effective inhibitors of $\mathrm{T}_{3}$ uptake (30\% and 36\% inhibition of 15-min cellular uptake respectively). At 15-min incubation time, $38 \%$ of the total cell-associated $\mathrm{T}_{3}$ was present in the cytosol and nucleus, and $62 \%$ remained associated to the plasma membrane. Unidirectional uptake rates did not saturate over a free $\mathrm{T}_{3}$ concentration range up to $3.9 \mu \mathrm{M}$. We have concluded that $\mathrm{T}_{3}$ uptake in neonatal rat cardiomyocytes occurs by an energy- and temperaturedependent mechanism that may include endocytosis and amino acid transport system $\mathrm{T}$, and is not sensitive to the $\mathrm{Na}^{+}$gradient. Elucidation of the molecular basis for the $\mathrm{T}_{3}$ transporter is the subject of current investigation.

Journal of Endocrinology (2001) 171, 183-192

\section{Introduction}

The heart is a major target organ for thyroid hormone action. Thyroid hormone-induced changes in cardiac function are achieved through activation of iodothyroninesensitive genes (Dillmann 1990, Gloss et al. 1999), or through indirect, non-genomic pathways (Craelius et al. 1990, Davis \& Davis 1993). Genomic tri-iodothyronine $\left(\mathrm{T}_{3}\right)$-mediated effects result from the association of the hormone to nuclear receptors that modify transcription of specific mRNAs, coding for, e.g. the $\alpha$-isoform of myosin heavy chain or sarcoplasmic reticulum $\mathrm{Ca}^{2+}$-ATPase (Rohrer et al. 1991). A prerequisite for binding to the nuclear receptor is transmembrane transport of the hormone and, in the past, a non-protein-mediated diffusion pathway for $T_{3}$ transport has been proposed (Lein \& Dowben 1961, Pardridge \& Mietus 1980). However, a diffusion pathway is unlikely due to the lipophilic nature of thyroid hormones which makes it energetically unfavorable to cross the membrane unfacilitated, as evidenced by results from electron spin resonance studies and experiments on artificial lipid bilayers (Lai et al. 1985, Chehín et al. 1999). Moreover, a transport mechanism would confer a regulatory step in thyroid hormone metabolism (Hennemann et al. 1998). For example, in patients with non-thyroidal illness or during starvation, plasma $T_{3}$ production by thyroxine $\left(\mathrm{T}_{4}\right)$ deiodination in the liver is decreased (Docter \& Krenning 1990), and Hennemann et al. (1993) showed that this resulted from a reduced cellular uptake of $\mathrm{T}_{4}$, not from defective $5^{\prime}$-deiodination. Thus, the transmembrane transport of thyroid hormones is important in the overall body thyroid hormone bioactivity.

Although the heart is one of the most responsive target organs to thyroid hormones, little is known about the mechanisms of transport of these hormones across the plasma membrane of the cardiomyocyte. During the past decade evidence has been presented for $T_{3}$ uptake through a pathway mediated by a specific carrier protein (Oppenheimer \& Schwartz 1985, Docter et al. 1987, Pontecorvi \& Robbins 1989, Kragie 1994, Everts et al. 
1996b) and for receptor-mediated endocytosis (Cheng 1983a). To our knowledge, only our previous report examines $\mathrm{T}_{3}$ transport in cardiomyocytes (Everts et al. 1996b). In the current report, we continue the investigation on the transport of $\mathrm{T}_{3}$ in the heart and its compartmentalization, using cultured neonatal cardiomyocytes of the rat as a model system. Since, in some organs, $\mathrm{T}_{3}$ and $\mathrm{T}_{4}$ share the same transporter (Everts et al. 1996a), uptake of $\mathrm{T}_{3}$ in cardiomyocytes was compared with that of $\mathrm{T}_{4}$. The substrate specificity of the putative transporter was further assessed by comparing the uptake of $\mathrm{T}_{3}$ with that of reverse $\mathrm{T}_{3}\left(\mathrm{rT}_{3}\right)$, and by testing the effects of 3,5-di-iodothyronine $\left(3,5-\mathrm{T}_{2}\right)$ and $3,3^{\prime}$-di-iodothyronine $\left(3,3^{\prime}-\mathrm{T}_{2}\right)$. Furthermore, a growing number of studies demonstrate that uptake systems for aromatic amino acids, e.g. system $\mathrm{L}$ and system $\mathrm{T}$, are involved in the transport of thyroid hormones (Everts et al. 1994, Mitchell et al. 1999, Ritchie et al. 1999). In our previous report, we investigated the effect of tyrosine and tryptophan on $\mathrm{T}_{3}$ uptake and suggested that part of the $T_{3}$ uptake may occur through these systems (Everts et al. 1996b). In the present report, we have continued these studies by examination of the dose-dependency of the effect of tryptophan (Trp), tyrosine (Tyr) and 2-aminobicyclo[2,2,1]heptane-carboxylic acid $(\mathrm{BCH})$, a system $\mathrm{L}$ inhibitor, on $\mathrm{T}_{3}$ uptake.

\section{Materials and Methods}

\section{Animals}

Wistar rats, 3-days-old and of both sexes, were obtained from laboratory stock (Utrecht University, The Netherlands). They were killed by decapitation, and the hearts were quickly dissected and processed as described below to obtain primary cultures of cardiomyocytes.

\section{Materials}

All reagents used for cell isolation and cell culture were obtained from Life Technologies BV (Breda, The Netherlands), with the exception of trypsin and deoxyribonuclease which were purchased from Boehringer (Mannheim, Germany). Polystyrene culture dishes (24 wells) were obtained from Corning Costar Europe (Badhoevedorp, The Netherlands). Iodothyronines ( $\mathrm{T}_{4}$, $\mathrm{T}_{3}, 3,3^{\prime}-\mathrm{T}_{2}, 3,5-\mathrm{T}_{2}$ ), monodansylcadaverine (MDC), oligomycin, ouabain, Trp, Tyr, sulfobromophthalein (BSP) and $\mathrm{BCH}$ were purchased from Sigma Chemical Co. (St Louis, MO, USA). $\left[{ }^{125} \mathrm{I}\right] \mathrm{T}_{3}(81 \cdot 4 \mathrm{TBq} / \mathrm{mmol}),\left[{ }^{125} \mathrm{I}\right] \mathrm{rT} \mathrm{r}_{3}$ $(24.4 \mathrm{TBq} / \mathrm{mmol})$ and $\left[{ }^{125} \mathrm{IT}_{4}(4.3 \mathrm{TBq} / \mathrm{mmol})\right.$ were purchased from NEN Life Science Products, Inc. (Boston, MA, USA).

\section{Cell culture}

Primary cultures of neonatal rat cardiomyocytes were prepared using a trypsin digestion method as described previously (Everts et al. 1996b, Verhoeven et al. 2001). An enriched myocardial fraction was obtained by including a preplating step $\left(60 \mathrm{~min}\right.$ at $37^{\circ} \mathrm{C} ; 5 \% \mathrm{CO}_{2}$; in $250 \mathrm{ml}$ culture flasks) to remove fibroblasts (Blondel et al. 1971). After this procedure, the preparation consisted of more than 90\% cardiomyocytes (van Heugten et al. 1994). Cardiomyocytes were seeded into 24-well culture dishes at a density of $1.0 \times 10^{6}$ cells per well, and cultured at $37^{\circ} \mathrm{C}$ in a $5 \% \mathrm{CO}_{2}$ atmosphere in 4:1 (w/w) Dulbecco's modified Eagle's medium (DMEM)-medium 199 (M199) supplemented with $5 \%$ horse serum (HS), $5 \%$ fetal calf serum (FCS), and $2 \%$ penicillin/streptomycin. One day after isolation the culture medium was replaced by fresh medium. Experiments were routinely performed after 5 days of culture at which time the cardiomyocytes reached confluency and were in a spontaneously and synchronously contracting monolayer (Verhoeven et al. 2001). Cell density was virtually constant, as the amount of total cellular protein per well $(30-40 \mu \mathrm{g})$ varied only slightly between preparations. Cell viability on the day of experimentation, as judged by the ability of cells to exclude trypan blue, was virtually $100 \%$. Although culture in the presence of serum might result in proliferation of fibroblasts that also show active uptake of $\left[{ }^{125} \mathrm{I}\right] \mathrm{T}_{3}$ and $\left[{ }^{125} \mathrm{I}\right] \mathrm{T}_{4}$ (Docter et al. 1987), it has previously been shown that uptake of $\left[{ }^{125} \mathrm{I}\right] \mathrm{T}_{3}$ and $\left[{ }^{125} \mathrm{I}\right] \mathrm{T}_{4}$ was similar in cardiomyocytes cultured in the absence and presence of serum (Everts et al. 1996b). Moreover, the uptake of $\left[{ }^{125} \mathrm{I}\right] \mathrm{T}_{3}$ expressed per $\mu \mathrm{g}$ protein is more than tenfold higher in cardiomyocytes than in cardiac fibroblasts ( $\mathrm{S}$ van der Heide, personal communication).

\section{Cellular uptake studies}

After removal of the culture medium, cardiomyocytes were preincubated for $30 \mathrm{~min}$ at $37^{\circ} \mathrm{C}$ in $0.5 \mathrm{ml}$ KrebsRinger buffer $(139 \mathrm{mM} \mathrm{NaCl}, 4.2 \mathrm{mM} \mathrm{KCl}, 1.5 \mathrm{mM}$ $\mathrm{CaCl}_{2}, 1.4 \mathrm{mM} \mathrm{KH}_{2} \mathrm{PO}_{4}, 1.4 \mathrm{mM} \mathrm{MgSO}, 5.0 \mathrm{mM}$ glucose; prepared in Tris at $\mathrm{pH} 7 \cdot 4$ ) supplemented with $0.5 \%$ bovine serum albumin (BSA). Incubation was initiated by quickly replacing the preincubation medium with $0.5 \mathrm{ml} \mathrm{Krebs}-$ Ringer buffer containing the additions described below and $\left[{ }^{125} \mathrm{I}^{\mathrm{T}} \mathrm{T}_{3}\left(4 \times 10^{5}\right.\right.$ c.p.m. $\left./ \mathrm{ml} ; 82 \mathrm{pM}\right)$, $\left[{ }^{125} \mathrm{I}\right] \mathrm{rT}_{3} \quad\left(4 \times 10^{5}\right.$ c.p.m. $\left./ \mathrm{ml} ; 273 \mathrm{pM}\right)$ or $\left[{ }^{125} \mathrm{I}\right] \mathrm{T}_{4}$ $\left(4 \times 10^{5}\right.$ c.p.m. $\left./ \mathrm{ml} ; 1 \cdot 6 \mathrm{nM}\right)$. The concentrations of BSA and iodothyronines in our incubation media were chosen so as to resemble free plasma hormone concentrations in the neonatal rat. Incubations were performed at $37{ }^{\circ} \mathrm{C}$, and the culture wells were mildly agitated. Uptake was terminated by quick aspiration of the incubation medium, and culture wells were rinsed three times with $1 \mathrm{ml}$ ice-cold saline. Cells were dissolved in $1 \mathrm{ml} 0 \cdot 1 \mathrm{M} \mathrm{NaOH}$ and analyzed for ${ }^{125} \mathrm{I}$ activity in a gamma-counter (Packard Cobra II, Packard Instruments Co., Meriden, CT, USA). The time-course of $T_{3}$ uptake was assayed in the presence or absence of sodium. Sodium-free conditions were 
attained by replacing sodium with choline on a mol-formol basis in the preincubation and incubation media. To test the temperature dependency of iodothyronine uptake, cardiomyocytes were preincubated and incubated at 0,20 or $37^{\circ} \mathrm{C}$. Unidirectional iodothyronine uptake was measured by incubation of cardiomyocytes for $5 \mathrm{~min}$ in Krebs-Ringer buffer containing $\left[{ }^{125} \mathrm{I}\right] \mathrm{T}_{3}$ and increasing concentrations of the unlabeled hormone $(10 \mathrm{nM}-$ $100 \mu \mathrm{M})$. Experiments in which the effect of analogues on 15-min $\mathrm{T}_{3}$ uptake was measured were performed by adding $10 \mu \mathrm{M}$ of the analogue to the Krebs-Ringer buffer containing $4 \times 10^{5}$ c.p.m. $/ \mathrm{ml}\left[{ }^{125} \mathrm{I}\right] \mathrm{T}_{3}$. In experiments in which the effects of oligomycin and MDC were investigated, they were added to both the preincubation and incubation medium. Possible involvement of other known transport systems in the uptake of $\left[{ }^{125} \mathrm{I}\right] \mathrm{T}_{3}$ was examined by preincubation and incubation with 0.5 or $2 \mathrm{mM}$ Tyr or Trp, 10 or $25 \mu \mathrm{M}$ BSP, or $5 \mathrm{mM} \mathrm{BCH}$.

The amount of $\left[{ }^{125} \mathrm{I}\right] \mathrm{T}_{3},\left[{ }^{125} \mathrm{I}\right] \mathrm{rT}_{3}$ or $\left[{ }^{125} \mathrm{I}\right] \mathrm{T}_{4}$ associated with the cells was expressed as either percentage of added ${ }^{125}$ I activity (percentage of dose) or as $\mathrm{pmol} / 10^{6}$ cells. Results were corrected for the amount of ${ }^{125} \mathrm{I}$ activity associated with the walls of the culture wells by subtracting the amount of ${ }^{125} \mathrm{I}$ activity extracted from the wells incubated without cells.

\section{Compartmentalization studies}

To distinguish $\left[{ }^{125} \mathrm{I}\right] \mathrm{T}_{3}$ activity partitioned within the plasma membrane from $\left[{ }^{125} \mathrm{I}\right] \mathrm{T}_{3}$ activity present in the cytosol, cardiomyocytes were treated with detergent to release cytosolic tracer contents. After incubation in Krebs-Ringer buffer, as described above, cells were treated at room temperature with a permeabilization buffer containing $50 \mu \mathrm{g} / \mathrm{ml}$ saponin in $160 \mathrm{mM} \mathrm{NaCl}$ and $5 \mathrm{mM}$ $\mathrm{MgCl}_{2}$ (pH 7.4). During permeabilization, the incubation wells were mildly agitated to ensure efficient exchange of cellular contents with the overlying medium. Saponin treatment effectively permeabilized the cells, as judged by the failure of treated cells to exclude trypan blue. Total protein content of cardiomyocytes did not change after permeabilization, indicating that saponin did not solubilize cells. After $30 \mathrm{~min}$, the medium was aspirated and analyzed for $\left[{ }^{125} \mathrm{I}\right] \mathrm{T}_{3}$ activity, which we interpreted to originate from the cytosol and, hence, resulting from the activity of the putative plasma membrane $T_{3}$ transport mechanism. After permeabilization, the remaining cellular debris was dissolved in $1 \mathrm{ml} 0 \cdot 1 \mathrm{M} \mathrm{NaOH}$ and analyzed for $\left[{ }^{125} \mathrm{I}\right] \mathrm{T}_{3}$ activity. We interpreted the latter activity to be mainly associated to the plasma membrane.

To isolate cell nuclei, the cellular debris remaining after treatment with saponin was scraped from the well using a rubber spatula and collected in $1 \mathrm{ml}$ ice-cold phosphatebuffered saline (PBS), pH $7 \cdot 4 \quad\left(42.5 \mathrm{mM} \mathrm{Na}_{2} \mathrm{HPO}_{4}\right.$, $7 \cdot 5 \mathrm{mM} \mathrm{NaH}_{2} \mathrm{PO}_{4}, 150 \mathrm{mM} \mathrm{NaCl}$ ). The well was rinsed once with $1 \mathrm{ml}$ ice-cold PBS, and both $1 \mathrm{ml}$ fractions were pooled and centrifuged at $300 \mathrm{~g}$ for $7 \mathrm{~min}$ at $4{ }^{\circ} \mathrm{C}$. The pellet thus obtained was dissolved and thoroughly mixed in $1 \mathrm{ml} \mathrm{0.5 \% (v/v)} \mathrm{Triton} \mathrm{X-100} \mathrm{in} \mathrm{PBS} \mathrm{and} \mathrm{centrifuged}$ at $900 \mathrm{~g}$ for $5 \mathrm{~min}$ at $4{ }^{\circ} \mathrm{C}$. This yielded a pellet consisting of nuclei with virtually no contamination by membrane or organelle fragments as judged from protein and DNA measurements. Pellet and supernatant were analyzed separately for $\left[{ }^{125} \mathrm{I}\right] \mathrm{T}_{3}$ activity. All results were corrected for the amount of $\left[{ }^{125} \mathrm{I}\right] \mathrm{T}_{3}$ activity collected from the wells in the absence of cells.

\section{Protein and DNA measurements}

Cellular protein was measured according to the method of Lowry et al. (1951). DNA was quantified using a Hoechst fluorescence staining method (Downs \& Wilfinger 1983).

\section{Free hormone fraction measurements}

Calculations of free $\mathrm{T}_{3}, \mathrm{rT}_{3}$ and $\mathrm{T}_{4}$ concentrations were based on the determinations of the free hormone fraction by equilibrium dialysis (Sterling \& Brenner 1966). In Krebs-Ringer buffer containing 0.5\% BSA and $82 \mathrm{pM}$ $\left[{ }^{125} \mathrm{I}\right] \mathrm{T}_{3}, 273 \mathrm{pM}\left[{ }^{125} \mathrm{I}\right] \mathrm{rT}$ or $1.6 \mathrm{nM}\left[{ }^{125} \mathrm{I}\right] \mathrm{T}_{4}$, the free hormone fractions were $2 \cdot 39 \pm 0 \cdot 2 \%(n=6), 1 \cdot 46 \pm 0 \cdot 02 \%$ $(n=3)$ and $0 \cdot 58 \pm 0 \cdot 04 \%(n=3)$ respectively (means \pm s.D. $)$. Furthermore, the free $\left[{ }^{125} \mathrm{I}\right] \mathrm{T}_{3}$ fractions in the presence of 1,10 or $100 \mu \mathrm{M}$ unlabeled $\mathrm{T}_{3}$ were $2 \cdot 54 \pm 0 \cdot 4 \%, 2 \cdot 92 \pm$ $0 \cdot 5 \%$ and $3 \cdot 90 \pm 0 \cdot 4 \%(n=3)$ respectively (means \pm s.D.). From the latter data a calibration curve was constructed to calculate unknown free $\left[{ }^{125} \mathrm{I}\right] \mathrm{T}_{3}$ fractions by interpolation.

\section{Statistics and calculations}

A single experiment consisted of duplicate or triplicate observations. Data are presented as means \pm S.E.M. unless stated otherwise. Statistical significance was evaluated by repeated measures ANOVA or Student's $t$-test, where appropriate. Statistical significance was accepted at $P<$ 0.05. Transport data were analyzed using a non-linear regression data analysis program.

\section{Results}

\section{$\left[{ }^{125} \mathrm{I}\right] \mathrm{T}_{3}$ uptake and $\mathrm{Na}^{+}$dependency}

Figure 1 shows the time-course of $\left[{ }^{125} \mathrm{I}\right] \mathrm{T}_{3}$ uptake. Hormone uptake leveled off after $30 \mathrm{~min}$. No significant difference was found between uptake of $\left[{ }^{125} \mathrm{I}\right] \mathrm{T}_{3}$ in the presence of $139 \mathrm{mM} \mathrm{Na}^{+}$or an equimolar concentration of choline in the incubation medium, indicating that $T_{3}$ uptake was not $\mathrm{Na}^{+}$dependent. This was corroborated by the observation that preincubation and incubation of 

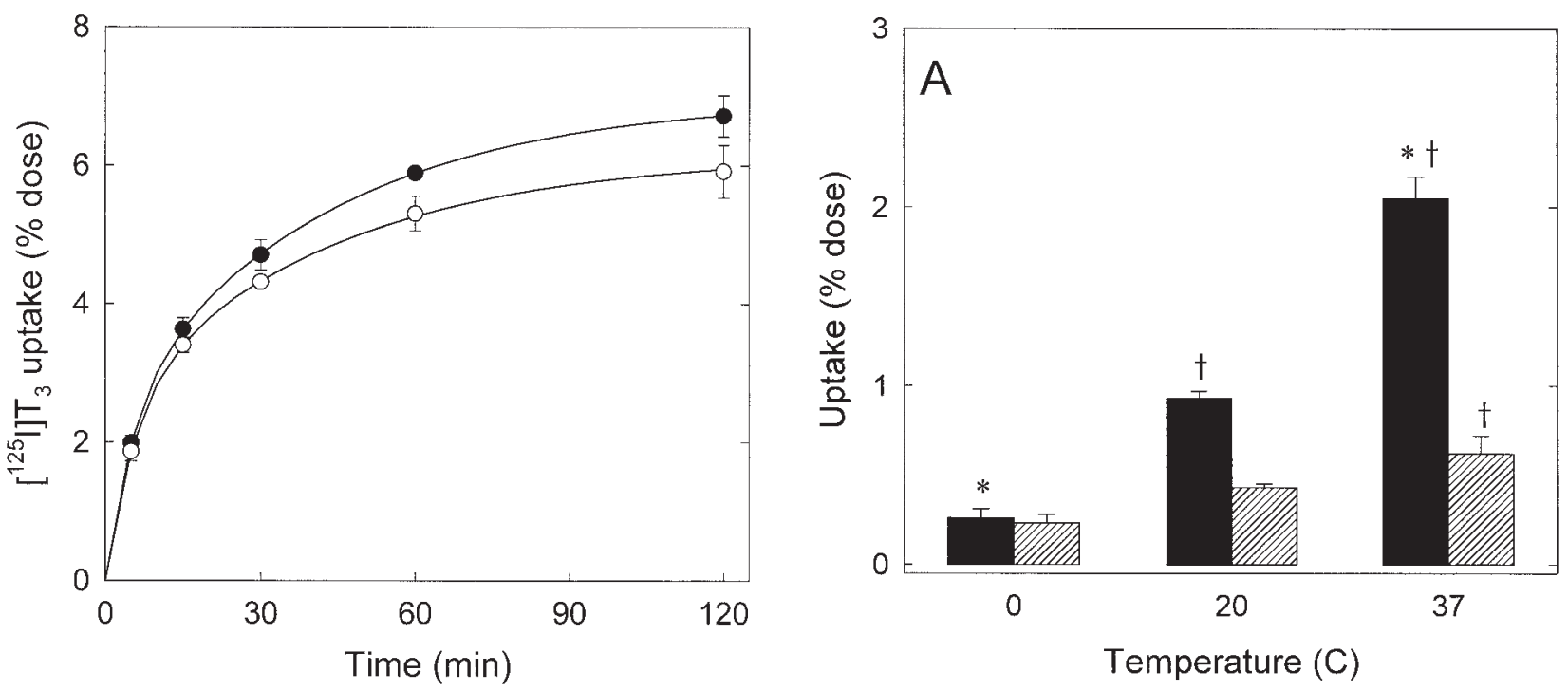

Figure 1 Time-course of $\left[{ }^{125} \mathrm{I}\right] \mathrm{T}_{3}$ uptake in neonatal cardiomyocytes. Cardiomyocytes from 3-day-old rats were cultured at a density of $1 \times 10^{6}$ cells/well for 5 days in DMEM/M199 supplemented with 5\% FCS-5\% HS. The uptake of $\left[{ }^{125} \mathrm{I}_{\mathrm{T}}\left(4 \times 10^{5}\right.\right.$ c.p.m./ml; $\left.82 \mathrm{pM}\right)$ was measured in Krebs-Ringer buffer with $\mathrm{Na}^{+}(-)$or in Krebs-Ringer buffer in which $\mathrm{Na}^{+}$was replaced by choline $(\bigcirc)$, both supplemented with $0.5 \%$ BSA. Incubations were performed at $37^{\circ} \mathrm{C}$. Means \pm S.E.M. of three experiments are shown.

cardiomyocytes with $1 \mathrm{mM}$ ouabain, an inhibitor of the plasma membrane sodium pump, did not affect the uptake of $\mathrm{T}_{3}$ (data not shown).

\section{Effects of temperature on iodothyronine uptake}

Figure 2 shows the temperature sensitivity of iodothyronine uptake by neonatal cardiomyocytes measured at 5 -min incubation time. Cellular $\left[{ }^{125} \mathrm{I}\right] \mathrm{T}_{3}$ uptake values, expressed as a percentage of the dose, increased 3.6- to $3 \cdot 8$-fold from 0 to $20{ }^{\circ} \mathrm{C}$ and $2 \cdot 2$ - to $2 \cdot 8$-fold from 20 to $37 \mathrm{C}^{\circ}(P<0 \cdot 001)$. Uptake of $\left[{ }^{125} \mathrm{I}\right] \mathrm{rT}_{3}$ at $20{ }^{\circ} \mathrm{C}$ was increased compared with $0{ }^{\circ} \mathrm{C}$; however, uptake did not rise significantly upon increasing the temperature from 20 to $37^{\circ} \mathrm{C}$ (Fig. 2A).

Figure $2 \mathrm{~B}$ shows that uptake of $\left[{ }^{125} \mathrm{I}\right] \mathrm{T}_{4}$, expressed as a percentage of the dose, rose $2 \cdot 8$ - and $2 \cdot 1$-fold upon increases in incubation temperature from 0 to $20^{\circ} \mathrm{C}$ and from 20 to $37^{\circ} \mathrm{C}$ respectively, the only statistically significant increase being from 0 to $37^{\circ} \mathrm{C}$. Compared with $\left[{ }^{125} \mathrm{I}\right] \mathrm{T}_{4}$, uptake of $\left[{ }^{125} \mathrm{I}\right] \mathrm{T}_{3}$ at $37^{\circ} \mathrm{C}$ was $2 \cdot 3$-fold higher.

Calculations of free $\mathrm{T}_{3}, \mathrm{rT}_{3}$ and $\mathrm{T}_{4}$ concentrations were based on determinations of the free fractions by equilibrium dialysis performed at $37^{\circ} \mathrm{C}$. Uptakes at $37^{\circ} \mathrm{C}$ of $\mathrm{T}_{3}$, $\mathrm{T}_{4}$ and $\mathrm{rT}_{3}$ expressed in $\mathrm{fmol} / \mathrm{pM}$ free hormone were $0 \cdot 36 \pm 0 \cdot 12(n=7), 0 \cdot 70 \pm 0 \cdot 28(n=4)$ and $0 \cdot 21 \pm 0 \cdot 03(n=3)$ respectively.

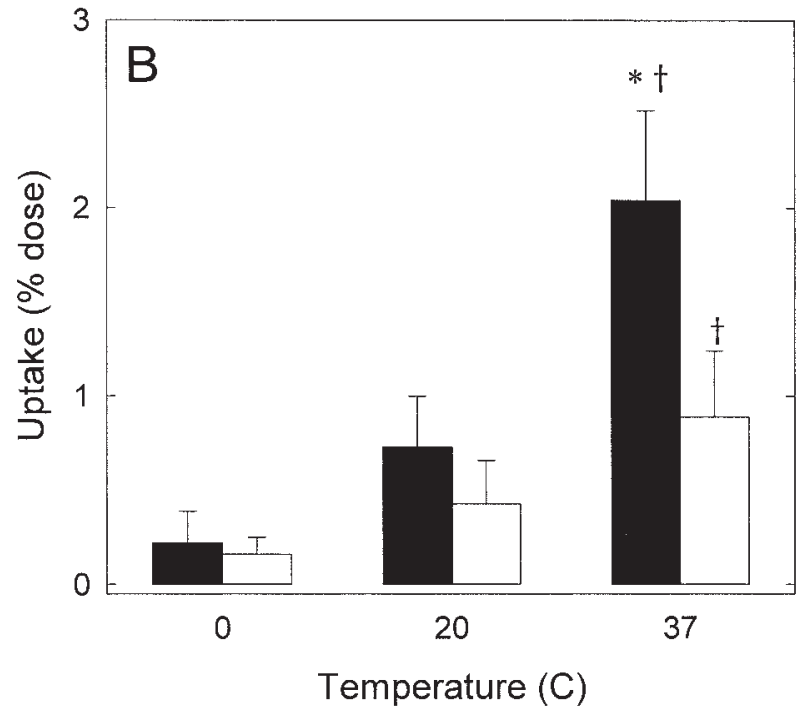

Figure 2 Effect of temperature in neonatal rat cardiomyocytes measured at 5-min incubation time of $\left.(\mathrm{A}){ }^{\left[{ }^{125} \mathrm{I}\right.}\right]_{3}$ (solid bars) and $\left[{ }^{125} \mathrm{I}\right] \mathrm{rT}_{3}$ (hatched bars) $(n=3)$ and $\left.(\mathrm{B}) \mathrm{[}^{125} \mathrm{I}\right] \mathrm{T}_{3}$ (solid bars) and ${ }^{125}{ }^{125} \mathrm{~T}_{4}$ (open bars) $(n=4)$. Uptake values are expressed as a percentage of the dose. $+P<0.05$ vs $0{ }^{\circ} \mathrm{C} ;{ }^{*} P<0.05$ vs $20{ }^{\circ} \mathrm{C}$.

\section{Effects of thyroid hormone analogues}

Fifteen-minute uptake of $\left[{ }^{125} \mathrm{I}\right] \mathrm{T}_{3}$ (total concentration: $82 \mathrm{pM}$ ) was significantly inhibited by $10 \mu \mathrm{M}$ unlabeled $\mathrm{T}_{3}$

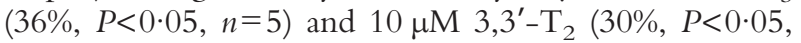
$n=4)$, while the effects of $3,5-\mathrm{T}_{2}(20 \%, n=4)$ and $\mathrm{T}_{4}$ $(22 \%, n=4)$ were not significant (data not shown).

\section{Effects of inhibitors on $\left[{ }^{125} I\right] T_{3}$ uptake}

To test the energy dependence of $\left[{ }^{125} \mathrm{I}\right] \mathrm{T}_{3}$ uptake and the possible involvement of endocytosis, cardiomyocytes were 


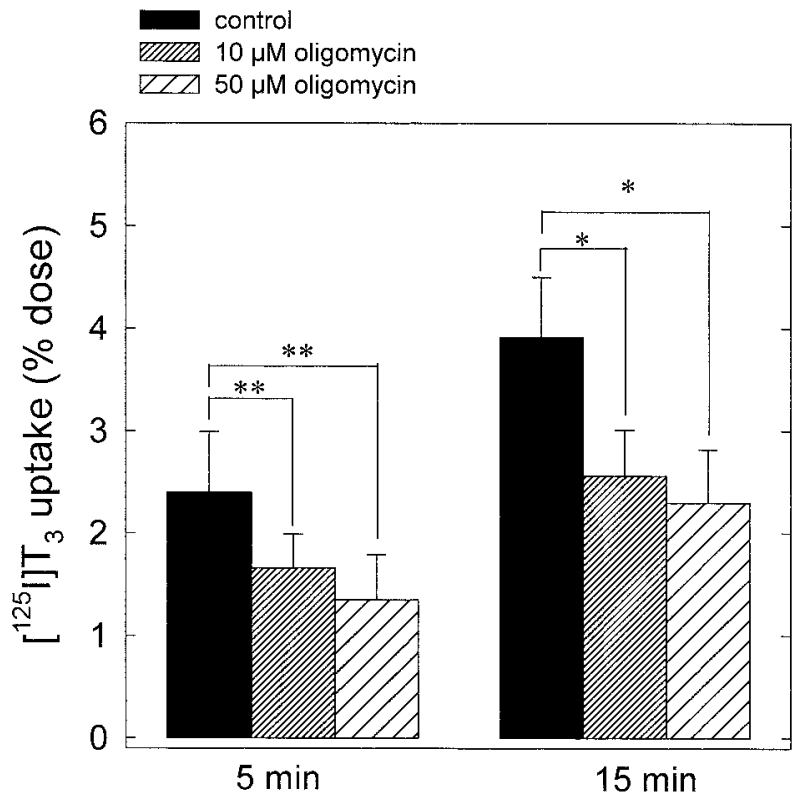

Figure 3 Effects of 10 and $50 \mu \mathrm{M}$ oligomycin on 5 -min $(n=3)$, and on 15-min $\left[{ }^{125}{ }^{1}\right] \mathrm{T}_{3}$ uptake $(n=4)$. Oligomycin was present during the preincubation $(30 \mathrm{~min})$ and incubation. ${ }^{*} P<0.05$ vs control; ${ }^{*} P<0 \cdot 01$ vs control.

incubated for 5 or $15 \mathrm{~min}$ with either 10 or $50 \mu \mathrm{M}$ oligomycin, or $100 \mu \mathrm{M}$ MDC. Oligomycin at a concentration of $50 \mu \mathrm{M}$ significantly inhibited $\left[{ }^{125} \mathrm{I}\right] \mathrm{T}_{3}$ uptake by $44 \%(P<0 \cdot 05)$ at $5 \mathrm{~min}$ and by $42-49 \%(P<0 \cdot 001)$ at $15 \mathrm{~min}$ (Fig. 3 and Table 1). MDC, an inhibitor of receptor-mediated endocytosis, reduced the uptake of $\left[{ }^{125} \mathrm{I}_{\mathrm{T}} \mathrm{T}_{3}\right.$ by $25 \%$ at $15 \mathrm{~min}(P<0 \cdot 001)$ (Table 1$)$. To examine whether oligomycin and MDC affected $\mathrm{T}_{3}$ transport through separate mechanisms, cardiomyocytes were preincubated and incubated for $15 \mathrm{~min}$ with $50 \mu \mathrm{M}$ oligomycin together with $100 \mu \mathrm{M}$ MDC. This

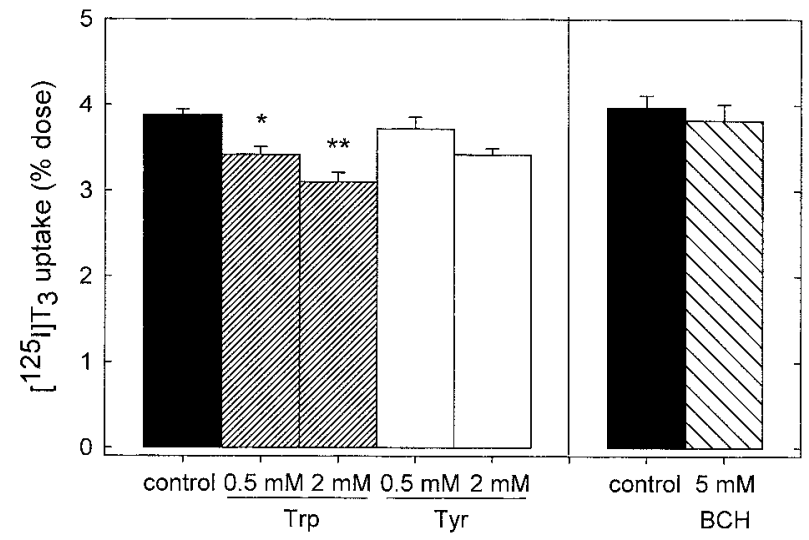

Figure 4 Effect of 0.5 and $2 \mathrm{mM}$ Trp, 0.5 and $2 \mathrm{mM}$ Tyr and $5 \mathrm{mM} \mathrm{BCH}$ on 15 -min uptake of $\left[{ }^{125} \mathrm{I}_{\mathrm{T}}\right.$. Substrates were present during preincubation and incubation. Data show means \pm S.E.M. of two to four experiments. ${ }^{*} P<0 \cdot 05$ vs control; ${ }^{*} P<0 \cdot 001$ vs control.

co-incubation resulted in a $47 \%$ reduction of $\mathrm{T}_{3}$ uptake, which was comparable to the effect of oligomycin alone (Table 1).

Participation of other transporters in $\left[{ }^{125} I\right] T_{3}$ uptake; effects of Trp, Tyr, BCH and BSP

To test the possible involvement of amino acid transport systems $\mathrm{T}$ and $\mathrm{L}$ in the uptake of $\left[{ }^{125} \mathrm{I}\right] \mathrm{T}_{3}$, cardiomyocytes were preincubated and incubated $(15 \mathrm{~min})$ with 0.5 or $2 \mathrm{mM}$ Trp, 0.5 or $2 \mathrm{mM}$ Tyr (substrates for system T and $\mathrm{L}$ ) or $5 \mathrm{mM} \mathrm{BCH}$, a specific system $\mathrm{L}$ inhibitor (Broer et al. 1998) (Fig. 4). Trp and Tyr showed a dosedependent inhibition of $\left[{ }^{125} \mathrm{I}_{\mathrm{T}}\right.$ uptake $(20 \%$ and $12 \%$ maximal inhibition), of which the effect of Trp was significant $(0.5 \mathrm{mM}, P<0 \cdot 05 ; 2 \mathrm{mM}, P<0 \cdot 001)$. Incubation with $\mathrm{BCH}$ showed no reduction of $15-\min \left[{ }^{125} \mathrm{I}\right] \mathrm{T}_{3}$ uptake (Fig. 4) nor of $60-$ min $\left[{ }^{125} \mathrm{I}\right] \mathrm{T}_{3}$ uptake (data not

Table 1 Effects of oligomycin, MDC, Trp and combinations of these compounds on 15-min uptake of $\left[{ }^{125} \mathrm{I}\right] \mathrm{T}_{3}$. Data show the means \pm S.E.M. of two to four experiments (shown in parentheses)

\author{
Experimental conditions \\ No additions \\ $+50 \mu \mathrm{M}$ oligomycin \\ $+100 \mu \mathrm{M}$ MDC \\ $+2 \mathrm{mM}$ Trp \\ $+50 \mu \mathrm{M}$ oligomycin $+100 \mu \mathrm{M}$ MDC \\ $+50 \mu \mathrm{M}$ oligomycin $+2 \mathrm{mM}$ Trp
}

\begin{tabular}{|c|c|c|}
\hline $\begin{array}{l}{\left[{ }^{125} \mathbf{I}\right] \mathbf{T}_{3} \text { uptake }} \\
(\% \text { dose })\end{array}$ & $\begin{array}{l}\text { Effect } \\
(\%)\end{array}$ & $\boldsymbol{P}$ \\
\hline $3 \cdot 82 \pm 0 \cdot 05(4)$ & & \\
\hline $1 \cdot 93 \pm 0 \cdot 13$ & -49 & $<0.001$ \\
\hline $2 \cdot 87 \pm 0 \cdot 11(4)$ & -25 & $<0.001$ \\
\hline $2 \cdot 98 \pm 0.07(3)$ & -22 & $<0.001$ \\
\hline $2 \cdot 04 \pm 0 \cdot 17(3) \dagger$ & -47 & $<0.001$ \\
\hline $0 \cdot 87 \pm 0.07(2)^{*}$ & -77 & $<0.001$ \\
\hline
\end{tabular}

The cardiomyocytes were preincubated $(30 \mathrm{~min})$ and incubated $(15 \mathrm{~min})$ in the absence or presence of oligomycin, MDC, Trp, oligomycin with MDC or oligomycin with Trp. The inhibitory effect of these compounds on $\left[{ }^{125} 1\right] \mathrm{T}_{3}$ uptake is compared with no additions and expressed as \%.

Statistical differences between additions and no additions are indicated. $\uparrow P<0 \cdot 001$, oligomycin + MDC vs MDC alone; ${ }^{*} P<0 \cdot 001$ oligomycin + Trp vs oligomycin or Trp alone. 
shown). The combined effect of $50 \mu \mathrm{M}$ oligomycin and $2 \mathrm{mM}$ Trp was tested in two experiments and showed a larger and additive reduction of $\left[{ }^{125} \mathrm{I}\right] \mathrm{T}_{3}$ uptake $(77 \%$, $P<0 \cdot 001)$ compared with the effects of the two compounds alone (49\% and $22 \%$ respectively) (Table 1$)$. In addition, possible participation of an organic anion transport system in the uptake of $\left[{ }^{125} \mathrm{I}_{\mathrm{T}} \mathrm{T}_{3}\right.$ was examined in two independent experiments by preincubation and incubation for $5 \mathrm{~min}$ with 10 or $25 \mu \mathrm{M}$ BSP. BSP is transported by members of the family of organic anion transporters (OATP family) (Wolkoff 1996). This gave the following values as percentage of the dose: controls, $2 \cdot 36 \pm 0 \cdot 16(n=8) ; 10 \mu \mathrm{M}$ BSP, $2 \cdot 51 \pm 0 \cdot 18(n=4) ; 25 \mu \mathrm{M}$ BSP, $2 \cdot 22 \pm 0 \cdot 30(n=4)$, showing that BSP does not inhibit $\mathrm{T}_{3}$ uptake.

\section{Substrate-dependent unidirectional uptake}

From Fig. 1 we chose a time-point of $5 \mathrm{~min}$ to measure unidirectional $\mathrm{T}_{3}$ uptake rates. Figure $5 \mathrm{~A}$ shows that unidirectional uptake rate of $\mathrm{T}_{3}$, although not adequately described by a straight line, does not saturate over a total $\mathrm{T}_{3}$ concentration ranging from $10 \mathrm{nM}$ to $100 \mu \mathrm{M}$. When $\mathrm{T}_{3}$ uptake data were analyzed as a function of the free $\mathrm{T}_{3}$ concentration, the curve describing cellular uptake deviated notably from a straight line (Fig. 5B). Although uptake data appeared to converge on a rectangular hyperbola, the curve could not be adequately described by simple saturation kinetics.

\section{Compartmentalization of $T_{3}$}

Our observation of the apparent non-saturability of cellular $\mathrm{T}_{3}$ uptake rates prompted us to investigate the passive incorporation of the lipophilic tri-iodothyronine in the plasma membrane as a possible confounding factor in our uptake assays. After an incubation period of $15 \mathrm{~min}$ and following detergent treatment of the cardiomyocytes, 35\% of the total $\left[{ }^{125} \mathrm{I}\right] \mathrm{T}_{3}$ activity in the cells was retrieved in the cytosolic fraction. The plasma membrane fraction contained $62 \%$ of the total $\left[{ }^{125} \mathrm{I}\right] \mathrm{T}_{3}$ activity, and $3 \%$ was incorporated in the nuclei. After an incubation period of $120 \mathrm{~min}$, total cellular $\left[{ }^{125} \mathrm{I}\right] \mathrm{T}_{3}$ activity was increased $2 \cdot 2$-fold compared with $15 \mathrm{~min}$. Now, $50 \%$ of the total $\left[{ }^{125} \mathrm{I}\right] \mathrm{T}_{3}$ activity was associated with the membrane, and $47 \%$ was recovered from the cytosolic fraction, while 3\% was incorporated into the nuclei (Table 2). In one experiment we determined the recovery of DNA in the nuclear fraction. As the DNA content of intact cells amounted to $6 \cdot 8 \pm 0 \cdot 6 \mu \mathrm{g}$ DNA $/ 0.5 \times 10^{6}$ cells $(n=3)$, DNA content of the isolated nuclear fractions after 15 and 120 min amounted to $4 \cdot 9 \pm 0.3 \mu \mathrm{g}$ DNA $/ 0.5 \times 10^{6}$ cells $(n=3)\left(72 \%\right.$ recovery) and to $5 \cdot 0 \pm 0 \cdot 1 \mu \mathrm{g}$ DNA $/ 0.5 \times 10^{6}$ cells $(n=3)$ (74\% recovery) respectively.

We again determined the unidirectional $\mathrm{T}_{3}$ uptake rate as a function of the free $T_{3}$ concentration, but now
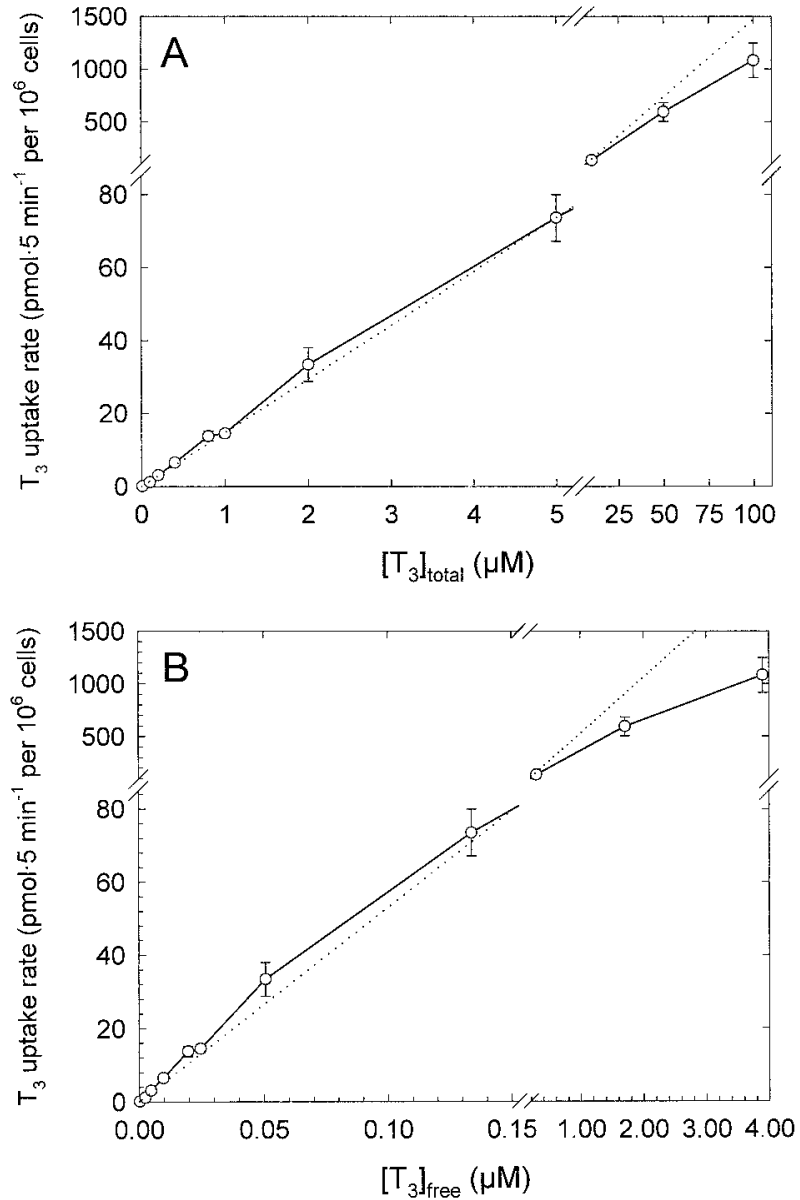

Figure 5 Unidirectional $T_{3}$ uptake rates as a function of $(A)$ the total $T_{3}$ concentration and $(B)$ the calculated free $T_{3}$ concentration. The dotted line shows the result of a non-linear regression analysis of the data points to the linear function $y=a x+b$, indicating the deviation of the data from a straight line. Data points represent the mean \pm S.E.M. of three to seven experiments. Please note the different abscissa ranges in panels $\mathrm{A}$ and $\mathrm{B}$.

measuring the $\left[{ }^{125} \mathrm{I}\right] \mathrm{T}_{3}$ activity released from the cytosol by detergent treatment and the $\left[{ }^{125} \mathrm{I}\right] \mathrm{T}_{3}$ activity remaining in the plasma membrane after permeabilization. Figure 6 shows that the uptake rates measured in the membranebound and cytosolic fraction did not saturate over a free $\mathrm{T}_{3}$ concentration ranging from $25 \mathrm{nM}$ to $3.9 \mu \mathrm{M}$.

\section{Discussion}

The main outcome of this study was that the uptake of $\mathrm{T}_{3}$ in neonatal rat cardiomyocytes (cultured with serum) is temperature dependent, MDC, oligomycin and Trp sensitive, but not dependent on the $\mathrm{Na}^{+}$gradient. Apart from the $\mathrm{Na}^{+}$dependency (see below), this confirms our observations in cardiomyocytes cultured in the absence of serum 
Table 2 Compartmentalization of $\mathrm{T}_{3}$ in membrane, cytosol and nucleus of cardiomyocytes. Cardiomyocytes were incubated and treated with saponin as described in Materials and Methods. Data show the mean \pm S.D. of two (15-min uptake) to four (120-min uptake) different preparations

\section{$\left[{ }^{125} \mathrm{I}\right] \mathrm{T}_{3}$ uptake (\% dose)}

\section{$\%$ of whole} cellular uptake

\section{Fraction}

15 min

Membrane

Cytosol

Nucleus

Total

$120 \mathrm{~min}$

Membrane

Cytosol

Nucleus

Total

$$
\begin{aligned}
1 \cdot 4 & \pm 0 \cdot 03 \\
0 \cdot 8 & \pm 0 \cdot 02 \\
0 \cdot 06 & \pm 0 \cdot 001 \\
2 \cdot 2 & \pm 0 \cdot 06 \\
2 \cdot 5 & \pm 0 \cdot 5 \\
2 \cdot 3 & \pm 0 \cdot 2 \\
0 \cdot 17 & \pm 0 \cdot 03 \\
5 \cdot 0 & \pm 0 \cdot 43
\end{aligned}
$$

$$
\begin{gathered}
62 \pm 0 \cdot 1 \\
35 \pm 0 \cdot 1 \\
3 \pm 0 \cdot 1 \\
100 \\
50 \pm 6 \\
47 \pm 6 \\
3 \pm 0 \cdot 4 \\
100
\end{gathered}
$$

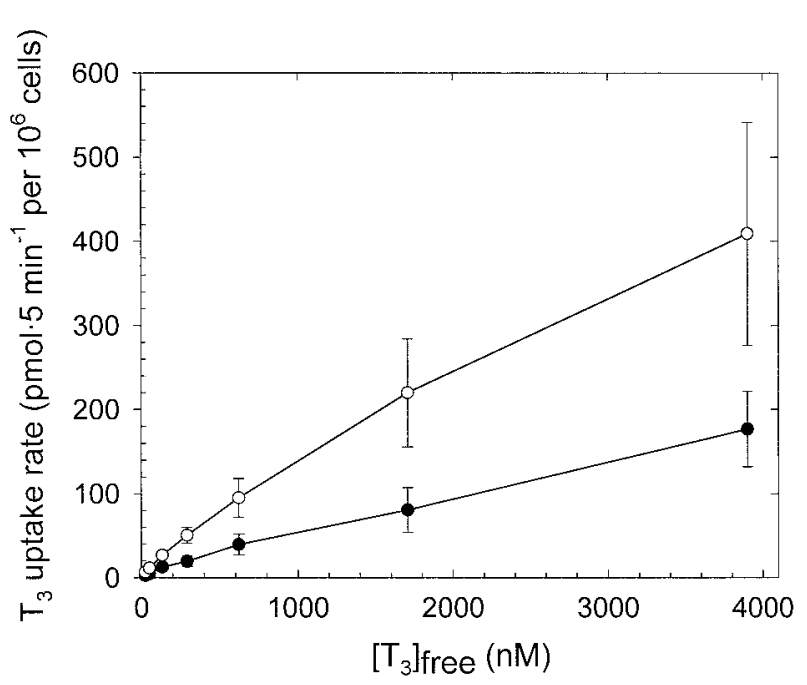

Figure 6 Unidirectional $T_{3}$ uptake rates in the membrane-bound $(\bigcirc)$ and cytosolic $(-)$ fractions of cultured neonatal cardiomyocytes as a function of the free $\mathrm{T}_{3}$ concentration. Data points represent the means \pm S.E.M. of three experiments.

(Everts et al. 1996b). The present study also included examination of the cellular compartmentalization of $\mathrm{T}_{3}$ showing that, although a high amount of $\mathrm{T}_{3}$ is associated with the plasma membrane, $\mathrm{T}_{3}$ is transported into the cytosol and to the nucleus. Finally, $\mathrm{T}_{3}$ uptake did not saturate at very high free hormone concentrations.

In our first study on thyroid hormone uptake in cardiomyocytes (Everts et al. 1996b), $\mathrm{T}_{3}$ uptake was found partly to be dependent on the $\mathrm{Na}^{+}$gradient as judged from the inhibitory effects $(20-30 \%)$ of $10 \mu \mathrm{M}$ monensin. In the present study where $\mathrm{Na}^{+}$dependency was judged from incubations with choline buffer, no such $\mathrm{Na}^{+}$dependency could be demonstrated. A similar discrepancy was previously observed when $\left[{ }^{125} \mathrm{I}\right] \mathrm{T}_{4}$ uptake by cultured anterior pituitary cells was examined (Everts et al. 1994).
While $\left[{ }^{125} \mathrm{I}\right] \mathrm{T}_{4}$ uptake was reduced by $40 \%$ in the presence of $10 \mu \mathrm{M}$ monensin, it was reduced by only $20 \%$ in choline-containing buffer (Everts et al. 1994). Probably, by inducing the $\mathrm{Na}^{+}$influx, monensin causes a more pronounced rundown of the $\mathrm{Na}^{+}$gradient across the plasma membrane, as compared with replacing the $\mathrm{Na}^{+}$by choline.

The present results indicate that neonatal rat cardiomyocytes possess a specific $T_{3}$ uptake system, as evidenced by the fact that $T_{3}$ itself is the most potent inhibitor of $\left[{ }^{125} \mathrm{I}\right] \mathrm{T}_{3}$ uptake and by the difference in temperature sensitivities between the uptake of $\mathrm{T}_{3}$ and its analogue $\mathrm{r} \mathrm{T}_{3}$. A plasma membrane receptor or an integral membrane carrier protein would confer substrate specificity to the $T_{3}$ transport mechanism but, to date, no such protein has been identified. It has been found, however, that a monoclonal antibody directed against an $M_{\mathrm{r}} 52000$ membrane protein inhibited $\mathrm{T}_{3}$ and $\mathrm{T}_{4}$ uptake in rat liver cells (Mol et al. 1986). This coincides remarkably with the observation that two $M_{\mathrm{r}} 53000$ and 55000 membraneassociated proteins were sensitive to $\mathrm{N}$-bromoacetyl$\left[{ }^{125} \mathrm{I}_{3} \mathrm{~T}_{3}\right.$ affinity labeling in cultured mouse fibroblasts (Cheng 1983b), a cell type shown to take up $\mathrm{T}_{3}$ by receptor-mediated endocytosis (Cheng 1983a). It remains to be investigated whether these observations are the manifestations of the putative $\mathrm{T}_{3}$ transporter/receptor.

In whole cell uptake experiments, a large amount of $T_{3}$ activity was associated to the plasma membrane. Similar findings were reported by others (Yusta et al. 1988, Chehín et al. 1999), and this is in line with the known lipophilicity of native iodothyronines (Pontecorvi \& Robbins 1989). The presence of this (non)-specific binding of substrate to the plasma membrane could explain why the time-course of $T_{3}$ uptake could not be adequately described by a single exponential. These results would imply that passive partitioning of the substrate in the lipid bilayer of the plasma membrane masks the uptake performed by a specific transport mechanism, thus confounding the results of whole cell uptake studies. In addition, several groups have described the presence of receptors at the plasma membrane which initiate non-genomic effects, e.g. modulation of $\mathrm{Na}^{+}$channels (Craelius et al. 1990, Davis \& Davis 1993). Association of $\mathrm{T}_{3}$ with these receptors presumably excludes uptake of the hormone. This warrants the use of a method which distinguishes membrane associated (non)-specific activity from that translocated across the plasma membrane by a transport system. We used a detergent treatment to determine this non-specific activity, resulting in values comparable with those reported by others (Cheng 1983a, Pontecorvi \& Robbins 1989). It is noteworthy that the magnitude of the unlabeled $\mathrm{T}_{3}$-inhibitable component in whole cell uptake (i.e. 36\%, see Results) is comparable with the fraction of $\mathrm{T}_{3}$ activity released from cardiomyocytes by detergent treatment (i.e. 35\%, see Table 2), both measured at $15 \mathrm{~min}$. Measurements after $2 \mathrm{~h}$ of incubation showed 
similar values (37\%) for the reduction of whole cell uptake by unlabeled $\mathrm{T}_{3}$ (Verhoeven et al. 2001). However, the large effect $(80 \%)$ on nuclear $\mathrm{T}_{3}$ binding after this incubation period (Verhoeven et al. 2001) and the increase of $\mathrm{T}_{3}$ activity in the cytosol (this report) indicate that $\mathrm{T}_{3}$ uptake is regulated by a specific mechanism at the plasma membrane.

Data on plasma thyroid hormone, especially $\mathrm{rT}_{3}$, concentrations in the neonatal rat are scant. From data in the literature we estimated values of $2-7 \mathrm{pM}$ free $\mathrm{T}_{3}$, 2-17 $\mathrm{pM}$ free $\mathrm{T}_{4}$ and $1 \mathrm{pM}$ free $\mathrm{rT}_{3}$ respectively (Rutgers et al. 1987, Rondeel et al. 1988, Aláez et al. 1992, Schröder-van der Elst \& van der Heide 1992), and we chose the composition of our incubation media to approximate to the free plasma hormone concentrations in the neonatal rat. The cardiomyocytes were exposed to $2 \mathrm{pM}$ free $\mathrm{T}_{3}, 10 \mathrm{pM}$ free $\mathrm{T}_{4}$ or $4 \mathrm{pMrT}$. This allowed us to compare thyroid hormone uptake in cardiomyocytes under physiological conditions. $\mathrm{T}_{3}$ uptake at $37^{\circ} \mathrm{C}$, expressed as percentage of dose, was higher than the uptake of $\mathrm{T}_{4}$ and $\mathrm{rT}_{3}$ (around two- and fourfold respectively). These results indicate that, under physiological conditions in vitro, cardiomyocytes take up thyroid hormone with a distinct preference for $\mathrm{T}_{3}$ over $\mathrm{T}_{4}$ and $\mathrm{rT}_{3}$. Taking into account the differences in experimental conditions (e.g. different BSA and total hormone concentrations, seeded cell densities), the present uptake values for $T_{4}$ and $T_{3}$ corresponded well with those reported in our previous study (Everts et al. 1996b).

The inhibition of $\mathrm{T}_{3}$ uptake by MDC hints at the involvement of receptor-mediated endocytosis in the transmembrane transport of the hormone in cardiomyocytes. This is corroborated by results from other studies presenting evidence for a physiological role for endocytosis in the uptake of substrates in rat cardiomyocytes (Iida \& Shibata 1989, Page et al. 1994). Not only in our cardiomyocyte preparation but also in other cell types, MDC was found to inhibit the uptake of $\mathrm{T}_{3}$ (Goncalves et al. 1989, Pontecorvi \& Robbins 1989, Everts et al. 1993, McLeese \& Eales 1996), suggesting that receptormediated endocytosis participates in cellular $\mathrm{T}_{3}$ uptake. The inhibitory effects of MDC and oligomycin on $\mathrm{T}_{3}$ uptake were not additive. Oligomycin affects the energy status of the cardiomyocyte by reducing its ATP content. Receptor-mediated endocytosis is an energy-dependent process (Barouch et al. 1994), and this would explain the inhibition by oligomycin. Further examination of the involvement of this process is the subject of current studies.

Neither in the presence nor in the absence of $\mathrm{Na}^{+}$could the uptake of $\mathrm{T}_{3}$ be adequately described by a single exponential, indicating the involvement of more than one component in $\mathrm{T}_{3}$ uptake by cardiomyocytes. Interestingly, the effects of co-incubation with oligomycin and Trp on $\mathrm{T}_{3}$ uptake were additive. It has been shown previously that members of the organic anion transporter family (rat
Oatp1-3, human OATP-C or liver-specific organic anion transporter (LST-1)) transport thyroid hormones in a $\mathrm{Na}^{+}$-independent manner (Abe et al. 1996, Friesema et al. 1999). Expression profiles show that some members of the OATP family are localized in the heart (Tamai et al. 2000). Furthermore, Abe et al. (1996) showed that BSP, which is an organic anion, inhibits OATP-mediated uptake of thyroid hormones. $T_{3}$ uptake in neonatal cardiomyocytes was not affected by BSP, indicating that this type of transporter is not involved in uptake of thyroid hormones in rat heart. Other likely candidates for a putative accessory transport system could be members of amino acid transport systems $\mathrm{T}$ or L. Both system $\mathrm{T}$ and $\mathrm{L}$ are $\mathrm{Na}^{+}$independent, and both systems transport aromatic amino acids (Kragie 1994, Palacín et al. 1998). It has been shown that the aromatic amino acids Tyr and Trp, which can be transported by both systems $\mathrm{L}$ and $\mathrm{T}$, inhibit the uptake of $\mathrm{T}_{3}$ in neonatal cardiomyocytes and transfected Xenopus oocytes (Everts et al. 1996b, Ritchie et al. 1999). Only system L is sensitive to the synthetic amino acid analogue $\mathrm{BCH}$ (Broer et al. 1998, Ritchie et al. 1999). Our results show that uptake of $\mathrm{T}_{3}$ was not sensitive to $\mathrm{BCH}$, from which we conclude that system $\mathrm{L}$ does not participate in uptake of $\mathrm{T}_{3}$ in neonatal rat cardiomyocytes. However, based on the inhibition of $\mathrm{T}_{3}$ uptake by Trp and Tyr shown in this report and the previous study in neonatal rat cardiomyocytes (Everts et al. 1996b), we cannot exclude system $\mathrm{T}$ as a candidate for a putative accessory transport system. We therefore plan to explore the participation of system $\mathrm{T}$ in uptake of thyroid hormones in cardiomyocytes further.

In summary, the results of our study on neonatal cardiomyocytes indicate the presence of an energy- and temperature-dependent uptake mechanism for $\mathrm{T}_{3}$ that is not dependent on the transmembrane $\mathrm{Na}^{+}$gradient. Based on the inhibitory effect of MDC, an endocytosis-mediated uptake mechanism cannot be excluded. Our data also suggest the presence an additional uptake system, e.g. amino acid transport system $\mathrm{T}$. We are currently deploying an expression-cloning strategy to further characterize the $\mathrm{T}_{3}$ uptake mechanism in neonatal rat cardiomyocytes.

\section{Acknowledgements}

The authors thank $\mathrm{TJ}$ Visser, $\mathrm{R}$ Docter and $\mathrm{ECH}$ Friesema (Department of Internal Medicine, Erasmus University Medical School, Rotterdam, The Netherlands) for constructive discussions. This work was supported by the Netherlands Heart Foundation (grant no. 96.175) and the Netherlands Organization for Scientific Research (grant no.15·17:039).

\section{References}

Abe T, Kakyo M, Sakagamii H, Tokui T, Nishio T, Tanemoto M, Nomura H, Hebert SC, Matsuno S, Kondo H \& Yawo H 1996 
Molecular characterization and tissue distribution of a new organic anion transporter subtype (oatp3) that transports thyroid hormones and taurocholate and comparison with oatp2. Journal of Biological Chemistry 273 22395-22401.

Aláez C, Calvo R, Obregón MJ \& Pascual-Leone AM 1992 Thyroid hormones and $5^{\prime}$-deiodinase activity in neonatal undernourished rats. Endocrinology $130773-779$.

Barouch W, Prasad K, Greene LE \& Eisenberg E 1994 ATPase activity associated with the uncoating of clathrin baskets by Hsp70. Journal of Biological Chemistry $26928563-28568$.

Blondel B, Roijen I \& Cheneval JP 1971 Heart cells in culture: a simple method for increasing the proportion of myoblasts. Experientia 27 356-358.

Broer A, Hamprecht B \& Broer S 1998 Discrimination of two amino acid transport activities in 4F2 heavy chain-expressing Xenopus laevis oocytes. Biochemical Journal 333 549-554.

Chehín RN, Issé BG, Rintoul MR \& Farías RN 1999 Differential transmembrane diffusion of triiodothyronine and thyroxine in liposomes: regulation by lipid composition. Journal of Membrane Biology 167 251-256.

Cheng SY 1983a Characterization of binding and uptake of $3,3^{\prime}, 5$-triiodothyronine in cultured mouse fibroblasts. Endocrinology $1121754-1762$.

Cheng SY $1983 b$ Structural similarities in the plasma membrane 3,3',5-triiodo-L-thyronine receptors from human, rat and mouse cultured cells. Analysis by affinity labeling. Endocrinology 113 $1155-1157$.

Craelius W, Green WL \& Harris DR 1990 Acute effects of thyroid hormone on sodium currents in neonatal myocytes. Bioscience Reports 10 309-315.

Davis PJ \& Davis FB 1993 Acute cellular actions of thyroid hormone and myocardial function. Annals in Thoracic Surgery 56 S16-S23.

Dillmann WH 1990 Biochemical basis of thyroid hormone action in the heart. American Journal of Medicine 88 626-630.

Docter R \& Krenning EP 1990 Role of cellular transport systems in the regulation of thyroid hormone bioactivity. In The Thyroid Gland, edn 1, pp 233-254. Ed. MA Greer. New York: Raven Press.

Docter R, Krenning EP, Bernard HF \& Hennemann G 1987 Active transport of iodothyronines into human cultured fibroblasts. Journal of Clinical Endocrinology and Metabolism 65 104-107.

Downs TR \& Wilfinger WW 1983 Fluorometric quantification of DNA in cells and tissues. Analytical Biochemistry 131 538-547.

Everts ME, Docter R, van Buuren JCJ, van Koetsveld PM, Hofland LJ, de Jong M, Krenning EP \& Hennemann G 1993 Evidence for carrier-mediated uptake of triiodothyronine in cultured anterior pituitary cells of euthyroid rats. Endocrinology 132 1278-1285.

Everts ME, Docter R, Moerings EPCM, van Koetsveld PM, Visser TJ, de Jong M, Krenning EP \& Hennemann G 1994 Uptake of thyroxine in cultured anterior pituitary cells of euthyroid rats. Endocrinology 134 2490-2497.

Everts ME, de Jong M, Lim C, Docter R, Krenning EP, Visser TJ \& Hennemann G 1996 a Different regulation of thyroid hormone transport in liver and pituitary: its possible role in the maintainance of low T3 production during nonthyroidal illness and fasting in man. Thyroid 6 357-366.

Everts ME, Verhoeven FA, Bezstarosti K, Moerings EPCM, Hennemann G, Visser TJ \& Lamers JMJ 19966 Uptake of thyroid hormones in neonatal rat cardiac myocytes. Endocrinology 137 4235-4242.

Friesema ECH, Docter R, Moerings EPCM, Stieger B, Hagenbuch B, Meier PJ, Krenning EP, Hennemann G \& Visser TJ 1999 Identification of thyroid hormone transporters. Biochemical and Biophysical Research Communications 254 497-501.

Gloss B, Sayen MR, Trost SU, Bluhm WF, Meyer M, Swanson EA, Usala SJ \& Dillmann WH 1999 Altered cardiac phenotype in transgenic mice carrying the $\Delta 337$ threonine thyroid hormone receptor $\beta$ mutant derived from the S family. Endocrinology 140 897-902.

Goncalves E, Lakshmanan M \& Robbins J 1989 Triiodothyronine transport into differentiated and undifferentiated mouse neuroblastoma cells (NB41A3). Endocrinology 124 293-300.

Hennemann G, Vos RA, de Jong M, Krenning EP \& Docter R 1993 Decreased peripheral 3,5,3'-triiodothyronine (T3) production from thyroxine (T4): a syndrome of impaired thyroid hormone activation due to transport inhibition of T4- into T3-producing tissues. Journal of Clinical Endocrinology and Metabolism 77 1431-1435.

Hennemann G, Everts ME, de Jong M, Lim C, Krenning EP \& Docter R 1998 The significance of plasma membrane transport in the bioavailability of thyroid hormone. Clinical Endocrinology $\mathbf{4 8}$ $1-8$.

van Heugten HAA, Bezstarosti K \& Lamers JMJ 1994 Endothelin-1 and phenylephrine-induced activation of the phosphoinositide cycle increases cell injury of cultured cardiomyocytes exposed to hypoxia/ reoxygenation. Journal of Molecular and Cellular Cardiology 26 15131524 .

Iida H \& Shibata Y 1989 Delivery of lectin-labeled membrane to the trans-Golgi network and secretory granules in cultured atrial myocytes. Journal of Histochemical Cytochemistry 37 1885-1892.

Kragie L 1994 Membrane iodothyronine transporters. Part I: Review of physiology. Endocrine Research 40 319-341.

Lai CS , Korytowski W, Niu CH \& Cheng SY 1985 Transverse motion of spin-labeled 3,3',5-triiodo-L-thyronine in phospholipid bilayers. Biochemical and Biophysical Research Communications 131 408-412.

Lein A \& Dowben RM 1961 Uptake and binding of thyroxine and triiodothyronine by rat diaphragm in vitro. American Journal of Physiology 200 1029-1031.

Lowry OH, Rosebrough NJ, Farr AL \& Randall RJ 1951 Protein measurement with the Folin phenol reagent. Journal of Biological Chemistry 193 265-275.

McLeese JM \& Eales JG 1996 Characteristics of the uptake of 3,5,3'triiodo-L-thyronine and L-thyroxine into red blood cells of rainbow trout (Oncorhynchus mykiss). General and Comparative Endocrinology 103 200-208.

Mitchell AM, Rowan KA, Manley SW \& Mortimer RH 1999 Comparison of mechanisms mediating uptake and efflux of thyroid hormones in the human choriocarcinoma cell line, JAR. Journal of Endocrinology 161 107-113.

Mol JA, Krenning EP, Docter R, Rozing J \& Hennemann G 1986 Inhibition of iodothyronine transport into rat liver cells by a monoclonal antibody. Journal of Biological Chemistry 261 7640-7643.

Oppenheimer JH \& Schwartz HL 1985 Stereospecific transport of triiodothyronine from plasma to cytosol and from cytosol to nucleus in rat liver, kidney, brain, and heart. Journal of Clinical Investigation 75 147-154.

Page E, Goings GE, Upshaw-Earley J, Hanck DA 1994 Endocytosis and uptake of lucifer yellow by cultured atrial myocytes and isolated intact atria from adult rats. Circulation Research 75 335-346.

Palacín M, Estévez R, Bertran J \& Zorzano A 1998 Molecular biology of mammalian plasma membrane amino acid transporters. Physiological Reviews 78 969-1054.

Pardridge WM \& Mietus LJ 1980 Influx of thyroid hormones into rat liver in vivo. Differential availability of thyroxine and triiodothyronine bound by plasma proteins. Journal of Clinical Investigation 66 367-374.

Pontecorvi A \& Robbins J 1989 The plasma membrane and thyroid hormone entry into cells. Trends in Endocrinology and Medicine $\mathbf{1}$ 90-94.

Ritchie JW, Peter GJ, Shi YB \& Taylor PM 1999 Thyroid hormone transport by 4F2 hc-IU12 heterodimers expressed in Xenopus oocytes. Journal of Endocrinology 163 R5-R9. 
Rohrer DK, Hartong R \& Dillman WH 1991 Influence of thyroid hormone and retinoic acid on slow sarcoplasmic reticulum $\mathrm{Ca}^{2+}$-ATPase and myosin heavy chain $\alpha$ gene expression in cardiac myocytes. Journal of Biological Chemistry 266 8638-8646.

Rondeel JM, de Greef WJ, van der Schoot P, Karels B, Klootwijk W \& Visser TJ 1988 Effect of thyroid status and paraventricular area lesions on the release of thyrotropin-releasing hormone and catecholamines into hypophysial portal blood. Endocrinology 123 523-527.

Rutgers M , Bonthuis F, de Herder WW \& Visser TJ 1987 Accumulation of plasma triiodothyronine sulfate in rats treated with propylthiouracil. Journal of Clinical Investigation 80 758-762.

Schröder-van der Elst JP \& van der Heide D 1992 Effects of streptozocin-induced diabetes and food restriction on quantities and source of T4 and T3 in rat tissues. Diabetes 41 147-152.

Sterling K \& Brenner MA 1966 Free thyroxine in human serum: simplified measurement with the aid of magnesium precipitation. Journal of Clinical Investigation 45 153-163.
Tamai I, Nezu J, Uchino H, Sai Y, Oku A, Shimane M \& Tsuji A 2000 Molecular identification and characterization of novel members of the human organic anion transporter (OATP) family. Biochemical and Biophysical Research Communications 273 251-260.

Verhoeven FA, Moerings EPCM, Lamers JMJ, Hennemann G, Visser TJ \& Everts ME 2001 Inhibitory effects of calcium blockers on thyroid hormone uptake in neonatal rat cardiac myocytes. American Journal of Physiology (In Press).

Wolkoff AW 1996 Hepatocellular sinusoidal membrane organic anion transport and transporters. Seminars in Liver Disease 16 121-127.

Yusta B, Ortiz-Caro J, Pascual A \& Aranda A 1988 Mechanism of L-triiodothyronine (T3) uptake by glial C6 cells: regulation by butyrate. Molecular and Cellular Endocrinology 58 191-198.

Received 5 June 2001

Accepted 26 June 2001 